DOI 10.22460/infinity.v7i2.p173-182

\title{
ATTITUDES TOWARD STATISTICS AND ACHIEVEMENT: BETWEEN STUDENTS OF SCIENCE AND SOCIAL FIELDS
}

\author{
Dian Cahyawati ${ }^{1}$, Wahyudin ${ }^{2}$, Sufyani Prabawanto ${ }^{3}$ \\ ${ }^{1}$ Universitas Sriwijaya, Jl. Palembang Prabumulih km 32 Ogan Ilir, South Sumatera, Indonesia \\ ${ }^{2,3}$ Universitas Pendidikan Indonesia, J1. Dr. Setiabudi No. 229, Bandung, West Java, Indonesia \\ 1'dianc_mipa@unsri.ac.id, ${ }^{2}$ wahyudin.mat@upi.edu, ${ }^{3}$ sufyani@upi.edu
}

Received: June 29, 2018 ; Accepted: September 08, 2018

\begin{abstract}
The purpose of this study was to explore students' attitudes toward statistics (ATS) based on the beginning and the end of learning, based on differences in fields of study, and examine its relationship with statistical acheivement. ATS was measured by an attitude instrument, namely The Survey of Attitudes toward Statistics (SATS) which consists of six dimensions (affective, cognitive competence, difficulty, value, interest, effort). Research respondents were undergraduate students who took lectures on statistical recognition that came from at one of the universities in South Sumatra. The results of the descriptive analysis showed the variation of ATS in each dimension of attitudes classified into positive, neutral, or negative attitudes. Although there are variations in the response of student attitudes in each dimension, but the results of statistical tests have not been able to show differences in attitudes between the beginning and the end of learning in each dimension. The differences in attitudes between the beginning and the end of learning that are statistically significant are in the dimensions of affective, value, and effort. The difference in the field of student science shows the difference in ATS, but only in the dimension of value. This study does not have enough evidence to state that there is a significant relationship between student attitudes to statistics and the results of learning statistics.
\end{abstract}

Keywords: Attitudes toward Statistics, Field of Study, Statistics Achievement.

\begin{abstract}
Abstrak
Tujuan penelitian ini adalah untuk mengeksplorasi sikap mahasiswa terhadap statistika (ATS) berdasarkan awal dan akhir pembelajaran, berdasarkan perbedaan bidang studi, dan menguji hubungannya dengan hasil belajar statistika. ATS diukur dengan instrumen sikap yaitu The Survey of Attitudes toward Statistic (SATS) yang terdiri dari enam dimensi (affective, competency cognitive, difficulty, value, interest, effort). Responden penelitian adalah mahasiswa tingkat sarjana yang mengikuti perkuliahan pengenalan statistika yang berasal dari salah satu perguruan tinggi di Sumatera Selatan. Hasil analisis deskripsi menunjukkan adanya variasi ATS pada setiap dimensi sikap yang diklasifikasikan menjadi sikap positif, netral, atau negatif. Meskipun terdapat variasi respon sikap mahasiswa pada setiap dimensi, tetapi hasil pengujian secara statistika belum dapat menunjukkan adanya perbedaan sikap antara awal dan akhir pembelajaran pada setiap dimensi. Perbedaan sikap antara awal dan akhir pembelajaran yang signifikan secara statistik ada pada dimensi affective, value, and effort. Perbedaan bidang ilmu mahasiswa menunjukkan adanya perbedaan ATS, tetapi hanya pada dimensi value. Penelitian ini belum memiliki cukup bukti untuk menyatakan bahwa ada hubungan yang signifikan antara sikap mahasiswa terhadap statistika dengan hasil belajar statistikanya.
\end{abstract}

Kata Kunci: Sikap terhadap Statistika, Bidang Ilmu, Hasil Belajar Statistika.

How to Cite: Cahyawati, D., Wahyudin, W., \& Prabawanto, S. (2018). Attitudes toward Statistics and Achievement: Between Students of Science and Social Fields. Infinity, 7(2), 173-182. doi:10.22460/infinity.v7i2.p173-182. 


\section{INTRODUCTION}

Statistics is a necessary and important topic in all education area. It is used by various disciplines and all levels of education (Andrews, 2010) from primary to university level (Chan \& Ismail, 2013). The importance of statistics makes this topic a compulsory course in higher education institutions (Ashaari, Judi, Mohamed, \& Tengku Wook, 2011). Similarly, in Indonesia, every program in higher education is required for including either mathematics or statistics or both of it (Menkumham-RI, 2005). That requirement aims to provide students' ability in basic understanding and applying quantitative methods. Especially for a statistics course, this topic is focused on statistical literacy, statistical reasoning, and statistical thinking those are essential abilities in the 21 st century.

The usefulness of statistics as a method for processing data in the various field was written by David Moore (Biehler, Ben-zvi, Bakker, \& Makar, 2013; Garfield \& Ben-Zvi, 2008). The importance of statistics as one of the scientific tools for suggesting to determine a decision in various experiment fields is the educators challenge to deliver the best learning for their students in improving statistics achievement.

Some observation to the statistics achievement from the first year undergraduate students in statistics introductory class in one of the universities at South Sumatera from 2016/2017 academic year found that there were only $49 \%$ of the 155 students who reached statistics achievement in top three (from 5-grades of quality) and the rest as much as $51 \%$ they reached in lower grades. It happened also in the previous academic years because of their difficulties in learning statistics, therefore some students tended to remedy statistics introductory class.

The difficulties in learning statistics can be related to cognitive and non-cognitive factors, but according to Ashaari et al. (2011) the dominant factor was non-cognitive factors. Learning motivation, learning interests, learning habits, self-concept, and attitudes was an example of a non-cognitive factor or an affective domain (Djaali, 2014) that can lead to difficulties in learning statistics (Ashaari et al., 2011). The attitudes toward statistics influence academic achievement (Hilton, Schau, \& Olsen, 2004). It can be a determinant factor in learning activities and a risk factor in academic achievement including statistics achievement.

The attitude has an important role in determining the students' learning atmosphere. A negative attitude can disturb in learning atmosphere both in the class (Liau, Kiat, \& Nie, 2014) and outside. Therefore, students' attitudes toward statistics are important to be studied and assessed (Hilton et al., 2004). The research on the attitudes toward statistics has been done for various purposes, among others aimed to reform the used of learning approaches, to improve academic achievement in statistics, as well as to improve the attitudes toward statistics itself.

There were out of 17 articles which conducted research about the attitudes toward statistics, but those articles were not yielded a similar result in conclusion (Ramirez, Schau, \& Emmioğlu, 2012). A total of 15 articles showed there was statistically relation between attitudes toward statistics and statistics achievement, but two other articles showed the different things. Jahan, Al-Saigul, \& Suliman (2016) examined the association between attitudes toward statistics and statistical ability and they expressed that someone who has positive attitudes toward statistics still indicated a difference in terms of statistical ability or achievement. Based on the major of studies, Ashaari et al. (2011) stated that there was no significant difference in attitudes toward statistics. These results showed that attitudes toward 
statistics and statistics achievement have not been consistent in its relationship. The meaning is the relationship of attitudes toward statistics and statistics achievement could be either statistically significant or statistically no significant.

This study aimed to explore students' attitudes toward statistics based on the beginning and the end of learning, based on differences in fields of study, and to examine the association between attitudes toward statistics and statistics achievement.

\section{METHOD}

The research method used the quantitative method. The population was the first year undergraduate students who joint statistics introduction class during the even semester in 2016/2017 academic year in one of the universities at South Sumatera. The sample research was chosen purposively from science fields and another from social field. Those fields were known respectively as a group of sci-tech and soc-hum as described by (Cahyawati, 2015).

The research variables were the attitude towards statistics, statistics achievement, academic achievement, and field of study. The attitude was defined psychologically (Ashaari et al., 2011; Chiesi \& Primi, 2009; Gal, Ginsburg, \& Schau, 1997; Hannula et al., 2016; Hilton et al., 2004; Jahan et al., 2016). Based on their definitions, operational variable of attitudes toward statistics (ATS) can be written as a tendency of students' respond on statistics topic.

The research instrument for measuring the ATS instrument was The Survey of Attitudes Toward Statistics (SATS) that was adopted from (Schau, 2004; 2008). The SATS scale uses 7-points Likert that is consisted of six dimensions and 36 items that can be descripted in Table 1.

Table 1. The Description of Attitude Dimensions

\begin{tabular}{clc}
\hline Dimension & \multicolumn{1}{c}{ Description } & \begin{tabular}{c}
\multicolumn{1}{c}{ Number of } \\
Item(s)
\end{tabular} \\
\hline Affective & students' positive or negative feeling about statistics & 6 \\
Cognitive & students' intelectual knowledge about statistics & 6 \\
Difficulty & students' attitude about the difficulty of statistics & 7 \\
Value & students' attitude about the usefulness, relevance, and worth & \\
& of statistics & 9 \\
Interest & students' level of individual interest in statistics & 4 \\
Effort & students' expends to learn and work in statistics & 4 \\
\hline
\end{tabular}

All of the SATS items in this study produced statistical high validity and reliability the same as other researchers who used the same instrument. The Cronbach's Alpha coefficient range was 0.71 to 0.85 except for the difficulty dimension was 0.56 . Nevertheless, that value is still acceptable for its reliability because all of the items in its dimension had the validity measure (Hair, Black, Babin, \& Anderson, 2014). The difficulty dimension had the lowest reliability coefficient that was in line with (García-Santillán, Escalera-Chávez, Rojas-Kramer, \& PozosTexon, 2014; Hilton et al., 2004; Schau, 2008; Schau, Dauphinee, Del Vecchio, \& Stevens, 1999; Tempelaar, Schim Van Der Loeff, \& Guselaers, 2007) in their research.

The other variable was academic achievement. It was a result of learning effort that related to aspects of knowledge (Arifin, 2016) and that was an outcome of education usually measured by a test or assessment (Kumari, 2014). Academic achievement was measured by a Grade 
Point Average (GPA). Statistics achievement or learning achievement (Yuwono, 2018) was measured by a final score on the statistics topic aslike (Liau et al., 2014) then it was transformed to 5-grades of quality value, namely A, B, C, D, and E.

The data was collected by asking students to give their respond about the SATS instrument. Students gave the respond twice, the first was at the beginning of the semester (pre-test data) and the second was at the end of the semester (post-test data). There were 118 respondents from 155 students who were participated in data collecting both of pre-test and post-test. The post-test data was analyzed by statistics descriptive. The age was ranging from 17 to 22 years. The most respondent about $70 \%$ was women. Then some statistical inferential test was used to answer the questions research.

\section{RESULTS AND DISCUSSION}

\section{Results}

\section{Attitudes toward Statistics}

Attitudes toward statistics can be expressed as a tendency of students' respond on statistics topic. Their respond can be a positive, neutral, or negative. Table 1 shows the descriptevely result of attitudes toward statistics from 118 students.

Table 1. Frequency and Percentage of each Attitudes Dimension

\begin{tabular}{|c|c|c|c|c|c|c|c|c|c|c|c|c|}
\hline \multirow{3}{*}{ Attitude } & \multicolumn{12}{|c|}{ Dimension } \\
\hline & \multicolumn{2}{|c|}{ Affective } & \multicolumn{2}{|c|}{ Cognitive } & \multicolumn{2}{|c|}{ Difficulty } & \multicolumn{2}{|c|}{ Value } & \multicolumn{2}{|c|}{ Interest } & \multicolumn{2}{|c|}{ Effort } \\
\hline & $f$ & $\%$ & $f$ & $\%$ & $f$ & $\%$ & $f$ & $\%$ & $f$ & $\%$ & $f$ & $\%$ \\
\hline Positive & 18 & 15.2 & 18 & 15.2 & 11 & 9.3 & 37 & 31.4 & 36 & 30.5 & 102 & 86.4 \\
\hline Neutral & 55 & 46.7 & 71 & 60.2 & 89 & 75.4 & 60 & 50.8 & 66 & 55.9 & 12 & 10.2 \\
\hline Negative & 45 & 38.1 & 29 & 24.6 & 18 & 15.3 & 21 & 17.8 & 16 & 13.6 & 4 & 3.4 \\
\hline
\end{tabular}

For knowing whether there were any differences attitude towards statistics between the beginning and the end of learning the t-test was done. Table 2 shows the result of statistical test to each dimensions of attitude.

Table 2. The Results of Statistical Test

\begin{tabular}{ccccccccc}
\hline \multirow{2}{*}{ Dimension } & \multicolumn{2}{c}{ Pretest } & \multicolumn{2}{c}{ Posttest } & \multirow{2}{*}{ N-Gain } & \multirow{2}{*}{ t } & p-value & $\begin{array}{c}\text { Effect Size } \\
\text { Cohen's d }\end{array}$ \\
\hline Affective & 4.95 & 1.17 & 4.50 & 0.98 & -0.22 & -4.01 & 0.000 & -0.41 \\
Cognitive & 4.36 & 0.95 & 4.31 & 0.75 & -0.02 & -0.61 & 0.542 & -0.06 \\
Difficulty & 3.27 & 0.81 & 3.32 & 0.78 & 0.01 & 0.62 & 0.539 & 0.07 \\
Value & 5.49 & 0.83 & 5.20 & 0.86 & -0.18 & -3.08 & 0.003 & -0.33 \\
Interest & 5.25 & 1.15 & 5.20 & 0.86 & -0.02 & -0.83 & 0.696 & -0.04 \\
Effort & 6.25 & 1.09 & 5.93 & 1.03 & -0.41 & -2.47 & 0.015 & -0.29 \\
\hline
\end{tabular}

\section{Attitudes toward Statistics based on The Fields of Study}

Figure 1 shows the mean score of students' response to each attitude dimensions based on the fields of study namely science and social fields. 


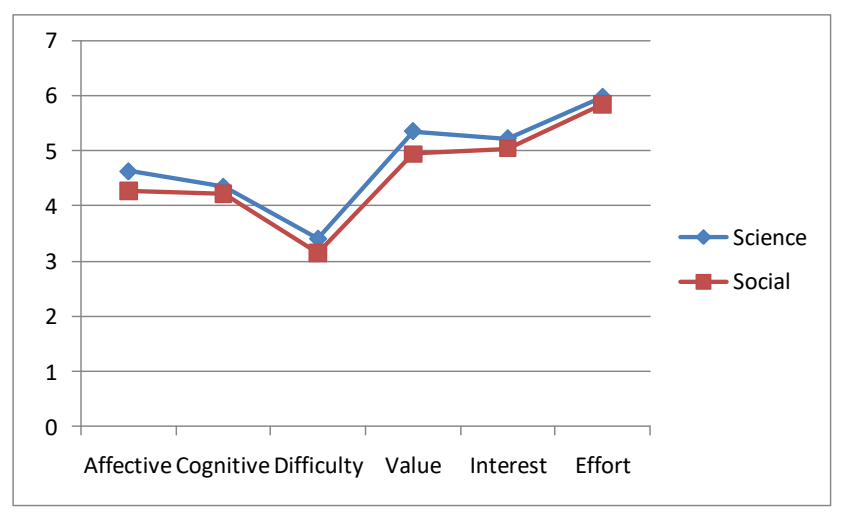

Figure 1. The Attitude Dimension Mean Scores based on The Field of Study

A t-test was carried out to find whether there was any difference in students' attitudes between science and social fields. The result of the test reached the sig. value $(p$-value $=0.01$ ) for the value dimension but $\mathrm{p}$-value $>0.05$ for other dimensions.

\section{Academic Achievement based on The Field of Study}

Statistics achievement was measured using 5-grades of quality value (A, B, C, D, and E) and academic achievement was measured using GPA. The students' statistics and academic achivements based on the field of study is shown in Figure 2

Then, a t-test conducted to see whether academic achievement between students of science field and students of social fields were different. The results was a significant difference in academic achievement between them $(\mathrm{t}=-13.082, \mathrm{p}<0.01)$.

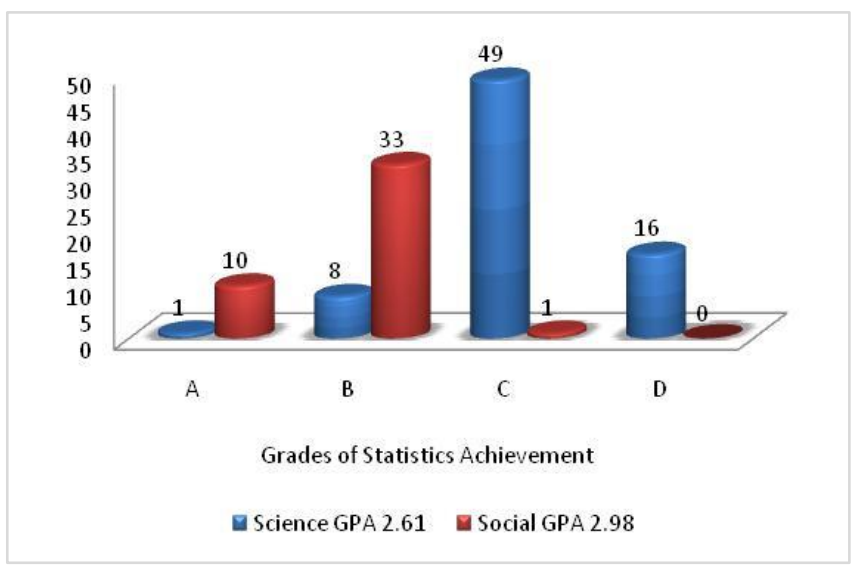

Figure 2. Statistics Achievement and The GPA based on the Fields of Study

\section{The Association between Attitudes toward Statistics and Statistics Achievement}

The Chi-Square test was carried out to find the association between students' attitude respond (positive, neutral, negative) and their statistics achievement (A, B, C, D, E).

Table 3. Pearson Chi-Square Test for Attitude Dimensions

\begin{tabular}{ccccccc}
\hline & Affective & Cognitive & Difficulty & Value & Interest & Effort \\
\hline Chi-Square & 8.494 & 8.042 & 2.339 & 16.159 & 3.868 & 5.707 \\
Df & 6 & 6 & 6 & 6 & 6 & 6 \\
Sig. & 0.204 & 0.235 & 0.886 & 0.013 & 0.695 & 0.457 \\
\hline
\end{tabular}


The outcome of correlation test among the attitude dimensions is shown on Table 4.

Table 4. Correlation Coefficient and Significant Value among Attitude Dimensions

\begin{tabular}{ccccccc}
\hline & Affective & $\begin{array}{l}\text { Cognitive } \\
\text { Competence }\end{array}$ & Difficulty & Value & Interest & Effort \\
\hline Affective & 0.619 & & & & \\
Cognitive & 0.285 & 0.370 & & & \\
Competence & & & & & \\
Difficulty & 0.323 & -0.105 & & \\
Value & 0.463 & $0.257)$ & & \\
Interest & 0.427 & 0.293 & -0.061 & 0.603 & \\
& & & $(0.515)$ & & \\
Effort & 0.386 & 0.098 & -0.291 & 0.579 & 0.561 & \\
& & $(0.290)$ & & & & \\
\hline
\end{tabular}

\section{Discussion}

\section{Attitudes toward Statistics}

Students responded the SATS instrument at the beginning and the end of the semester. Their response could be classified to the positive, neutral, or negative attitude. The data of the end of the semester, namely post-test data was chosen to classify students' response. The reason was the attitude at the end of the semester was a good predictor of statistics achievement as stated by Wisenbaker (Chiesi \& Primi, 2010). The post-test data descriptively was shown on the Table 1, there was a variation enough of students' response in each attitude dimensions

The effort dimension had the most percentage. All the items in this dimension were responded positively by students. This shows that students have had a good positive attitude in the effort to learn statistics. This result was in line with Ghulami, Hamid, \& Zakaria (2015) that found the students have given the great effort to learn statistics. The greater effort to learn statistics should reward a higher-quality grade in statistical achievement. Unfortunately, that was not shown in the next Figure 2. In that figure, students who got the low-quality grade in statistics achievement were quite a lot.

The only one dimension that was responded neutrally in all items was the interest dimension. This can be an indication that students have no good interest yet in statistics topic. They attended statistics course as a necessary one because the statistics course is one of the compulsory courses. Students had not interested yet in the statistics topic and that could be caused by many factors. One of them is historically the topic of statistics was a difficult and unpleasant discipline to study (Garfield \& Ben-Zvi, 2008).

However, they responded positively to the item "I can study statistics" in the instrument and believed in being able to learn statistics. They believed that statistics is a valuable topic but it was strangely enough, that other items about the value of statistics in daily life and occupation were still responding neutrally. This can happen because they were new students for the first year in higher education. They have not thought yet about the future field of work which they will be employed.

According to the Table 1, the largest percentage of positive attitudes was in the effort dimensions. The largest percentage of neutral attitudes exists in the difficulty dimension that 
was rather different with Ashaari et al. (2011) who classified the difficulty dimension into the positive attitude. The greatest percentage of negative attitudes was in the affective dimension that was in line with (Ashaari et al., 2011).

The statistical test was conducted to the pre-test and the post-test data for testing whether there were any differences of attitude between the beginning and the end of the learning process. The results of statistical test was shown on Table 2.

All of the N-Gain scores in Table 2 is less than 0.3 that means the changing in attitudes is in a low category (Hake, 1999). The p-value for t-test shows a significant negative change in the affective, value, and effort dimensions, while other dimensions were not. Some of the results are in contrast to Liau et al. (2014) which showed a positive change in both affective and cognitive competence dimensions, and no change in the value dimension as well. Some of the results are in line with Liau et al. (2014) whereas the effort dimension showed a negative change and both of the difficulty and interest dimensions did not show any change.

The negative changes in the attitude dimensions would be a problem because it indicates a decrease in attitudes responds to statistics topics. It would effect understanding, comforting, and enjoying in learning statistics and learning environment in the classroom as written by Gal et al. (Liau et al., 2014). Furthermore, the negative attitude has influence factor to their statistics achievement.

The score of Cohen's $d$ in Table 2 ranges from 0.04 to 0.33 which indicates the small effect criterion (Cohen, 1992; Thalheimer \& Cook, 2002). This shows that statistics introductory learning just carried out a very little effect on students' attitude changing. That means that pretest and posttest data were not significantly different, but for the next analysis, the postest data would be chosen to be used. The reason was that Wisenbaker (Chiesi \& Primi, 2010) stated that the attitude at the end of the semester was a good predictor of statistics achievement.

\section{Attitudes toward statistics based on The Fields of Study}

The t-test result showed that there were no significant different attitude in all attitude dimensions between the science and the social fields of study $(p>0.05)$ except for the value dimension $(\mathrm{p}=0.01)$ that indicated the existence of the difference students' attitude in the value dimension based on the fields of study. The result was in line with Griffith, Adams, Gu, Hart, \& Nichols-Whitehead (2012) who stated that majors differ with regard to general attitudes toward statistics. The resulting contrast to Ashaari et al. (2011) who stated the attitudes toward statistics was no significant difference based on the fields of study.

\section{The Association between Attitudes toward Statistics and Statistics Achievement}

Based on the result of Chi-Square test on Table 4, only the affective dimension shows a significant association with statistics achievement.This result was in line with Hilton et al. (2004) that stated a significant association between several components of attitudes toward statistics and course achievement (measured by test scores or course grades) although the association in small to moderate relations. However, there were some significant associations among attitude dimensions in small to moderate correlation coefficient as shows on Table 4. This means that the attitude towards statistics could be improved by paying attention to all dimension simultanously not only one by one dimensions. 


\section{CONCLUSION}

Attitudes toward statistics between students of science and students of social fields were different in the value dimension only. The value dimension means the students believed in a usefulness of statistics in their education, their life, and their future work. The mean score of science field students was higher than social field students. This suggests that the value of statistics need to be improved for students of the social field in order to reach their positive attitudes about statistics topic. This study has not been a success to show the association between attitudes toward statistics and statistics achievement. The characteristics of sample unit and sample size may be the reason. This has to be explored carefully for the next study.

\section{REFERENCES}

Andrews, S. (2010). Statistical Software for Teaching: Relevant, Appropriate and Affordable. In Proceeding of The Eight International Conference of Teaching Statistics (Vol. 8).

Arifin, Z. (2016). Evaluasi Pembelajaran: Prinsip, Teknik, dan Prosedur. Bandung: PT Remaja Rosdakarya.

Ashaari, N. S., Judi, H. M., Mohamed, H., \& Tengku Wook, T. M. (2011). Student's Attitude Towards Statistics Course. Procedia - Social and Behavioral Sciences, 18, 287-294. https://doi.org/10.1016/j.sbspro.2011.05.041

Biehler, R., Ben-zvi, D., Bakker, A., \& Makar, K. (2013). Technology for Enhancing Statistical Reasoning at the School Level. In Third international Handbook of Mathematics Education (pp. 643-689). New York: Springer. https://doi.org/10.1007/978-1-4614-4684-2

Cahyawati, D. (2015). The Interest of Prospective Students in Study Programs in Higher Education: a Preliminary Study. In The 6th International Conference on Educational, Management, Administration and Leadership (ICEMAL2016) (pp. 312-317).

Chan, S. W., \& Ismail, Z. (2013). Assessing Misconceptions in Reasoning About Variability Among High School Students. Procedia - Social and Behavioral Sciences, 93, 14781483. https://doi.org/10.1016/j.sbspro.2013.10.067

Chiesi, F., \& Primi, C. (2009). Assessing Statistics Attitudes among College Students: Psychometric Properties of The Italian Version of The Survey of Attitudes toward Statistics (SATS). Learning and Individual Differences, 19(2), 309-313. https://doi.org/10.1016/j.lindif.2008.10.008

Chiesi, F., \& Primi, C. (2010). Gender Differences in Attitudes Toward Statistics : Is There a Case for a Confidence Gap ?, 1-10.

Cohen, J. (1992). A Power Primer. Psychological Bulletin, 112(1). https://doi.org/10.1038/141613a0

Djaali. (2014). Psikologi Pendidikan. Jakarta: Bumi Aksara.

Gal, I., Ginsburg, L., \& Schau, C. (1997). Monitoring Attitudes and Beliefs in Statistics Education. In The Assessment Challenge in Statistics Education. Amsterdam: IOS Press.

García-Santillán, A., Escalera-Chávez, M. E., Rojas-Kramer, C. A., \& Pozos-Texon, F. J. (2014). Empirical Study on Students and Their Attitudes toward Statistics Course and Statistical Field. American Journal of Educational Research, 2(12), 1151-1159. https://doi.org/10.12691/education-2-12-4 
Garfield, J. B., \& Ben-Zvi, D. (2008). Developing Students' Statistical Reasoning: Connecting Research and Teaching Practice. New York: Springer.

Ghulami, H. R., Hamid, M. R. A., \& Zakaria, R. (2015). Students' Attitudes towards Learning Statistics. In AIP Conference Proceeding (Vol. 050035, p. 050035). https://doi.org/10.1063/1.4915668

Griffith, J. D., Adams, L. T., Gu, L. L., Hart, C. L., \& Nichols-Whitehead, P. (2012). Students' Attitudes Toward Statistics Across The Disciplines: A Mixed-Methods Approach. Statistics Education Research Journal, 11(2), 45-56.

Hair, J. F., Black, W. C., Babin, B. J., \& Anderson, R. E. (2014). Multivariate Data Analysis. New Jersey: Pearson.

Hake, R. R. (1999). Analyzing Change/Gain Scores. Unpublished.[Online] URL: Http://Www. Physics. Indiana. Edu^ Sdi/AnalyzingChange-Gain. Pdf. Retrieved from http://www.ncbi.nlm.nih.gov/pubmed/22025883\%5Cnhttp://scholar.google.com/scholar? $\mathrm{hl}=$ en\&btnG=Search\&q=intitle:ANALYZING+CHANGE/GAIN+SCORES\#0\%5Cnhttp ://scholar.google.com/scholar?hl=en\&btnG=Search\&q=intitle:Analyzing+change/gain+s cores $\% 230$

Hannula, M. S., Di Martino, P., Pantziara, M., Zhang, Q., Morselli, F., Heyd-Metzuyanim, E., ... Goldin, G. A. (2016). Attitudes, Beliefs, Motivation and Identity in Mathematics Education: An Overview of the Field and Future Direction (ICME 13). Hamburg: Springer Open. https://doi.org/10.1007/978-3-319-32811-9

Hilton, S. C., Schau, C., \& Olsen, J. A. (2004). Survey of Attitudes Toward Statistics: Factor Structure Invariance by Gender and by Administration Time. Structural Equation Modeling: A Multidisciplinary Journal, 11(1), 92-109. https://doi.org/10.1207/S15328007SEM1101_7

Jahan, S., Al-Saigul, A. M., \& Suliman, A. A. (2016). Attitudes to Statistics in Primary Health Care Physicians, Qassim Province. Primary Health Care Research \& Development, 17(04), 405-414. https://doi.org/10.1017/S1463423615000535

Kumari, B. (2014). The Correlation of Personality Traits and Academic Performance: A Review of Literature. IOSR Journal Of Humanities And Social Science (IOSR-JHSS), 19(4), 15-18.

Liau, A. K., Kiat, J. E., \& Nie, Y. (2014). Investigating the Pedagogical Approaches Related to Changes in Attitudes Toward Statistics in a Quantitative Methods Course for Psychology Undergraduate Students. Asia-Pacific Education Researcher, 24(2), 319327. https://doi.org/10.1007/s40299-014-0182-5

Menkumham-RI. (2005). Peraturan Pemerintah Nomor 19 Tahun 2005 tentang Standar Nasional Pendidikan. https://doi.org/10.1007/s13398-014-0173-7.2

Ramirez, C., Schau, C., \& Emmioğlu, E. (2012). The Importance of Attitudes in Statistics Education. Statistics Education Research Journal, 11(2), 57-71.

Schau, C. (2004). Scoring the SATS-28 @ , 21-22.

Schau, C. (2008). Common issues in SATS (C) research. Joint Statistical Meetings Proceedings, 1-4.

Schau, C., Dauphinee, T. L., Del Vecchio, A., \& Stevens, J. (1999). Survey of Attitudes toward Statistics (SATS). Retrieved January, 2, 2006. 
182 Cahyawati, Wahyudin \& Prabawanto, Attitudes toward Statistics and Achievement ...

Tempelaar, D. T., Schim Van Der Loeff, S., \& Guselaers, W. H. (2007). A Structural Equation Model Analyzing The Relationship of Students' Toward Statistics. Statistics Education Research Journal, 6(2).

Thalheimer, W., \& Cook, S. (2002). How to Calculate Effect Sizes from Published Research: A Simplified Methodology. Work-Learning Research, (August), 1-9. https://doi.org/10.1113/jphysiol.2004.078915

Yuwono, M. R. (2018). The Correlation between Cognitive Style and Students' Learning Achievement on Geometry Subject. Infinity Journal of Mathematics Education, 7(1), 35-44. https://doi.org/10.22460/infinity.v7i1.p35-44 